\title{
Analysis of the Application of Government Accounting Systems in Badan Pengelola Keuangan dan Aset Daerah Kabupaten Madiun
}

\author{
Galuh Tiaramurti ${ }^{1}$, Tituk Dyah Widjajatie ${ }^{2}$, Dwi Suhartini ${ }^{3}$ \\ \{galuh.tiara31@gmail.com ${ }^{1}$, titukdiahwidayantie@gmail.com² ${ }^{2}$ suhartinidwi7@gmail.com ${ }^{3}$ \} \\ 1,2,3UPN Veteran Jawa Timur, Raya Rungkut Madya Street, Surabaya, Indonesia
}

\begin{abstract}
In the Indonesian Government the policies adopted regarding Government Accounting Standards were implemented in Government Regulation No. 71 of 2010 and Minister of Home Affairs Regulation No. 64 of 2013. This existing policy concerns Accrual-Based Government Accounting Standards. In the Regional Government Accounting there are accounting entities and reporting entities, in this case the Regional Financial and Asset Management Agency of Madiun Regency is a reporting entity, which will record the financial statements of all accounting entities. In this study, it is known that the implementation of the accounting system in the Regional Financial and Asset Management Agency is good, except that each Regional Government Organization must be able to work together with the Regional Financial Management Unit so that the system is not hampered and facilitated.
\end{abstract}

Keywords: Government Accounting System, Regional Financial Management Work Unit,Policy.

\section{Introduction}

For the sake of implementing good governance, Indonesia, which is a state of law, makes laws and regulations. Likewise in financial management. Then all stakeholders must comply with applicable laws and regulations. The development of government accounting was rapidly influenced by the reform era which ultimately resulted in three packages of laws in the field of state finance, namely Law Number 17 of 2003 concerning State Finance, Law Number 1 of 2004 concerning State Treasury, Law Number 15 of 2004 concerning Inspections of Management and Responsibility of State Finances.

Government accounting is an accounting mechanism that processes financial transactions related to managing state finances. So basically government accounting which is a public sector accounting group consists of two systems, namely, the central government accounting system and the regional financial accounting system. The accounting system in Indonesia in addition to having the 1945 Constitution as the legal basis for everything that exists in Indonesia, also has a law governing State Finance, namely article 32 paragraph 1 No. 17 of 2003 which mandates that the accountability report in the form of financial statements, must arranged and presented in accordance with government accounting standards.

Based on the results of the discussion of the macroeconomic framework and the points of fiscal policy, the Central Government together with the DPR discussed general policies and 
budget priorities to be used as a reference for each State Ministry / Institution in preparing budget proposals. In this case the minister / head of the institution as the user of the budget compiles the Work Plan and Budget of the State Ministry / Institution (RKA-KL) the following year. The RKA-KL was submitted to the DPR to discuss the preliminary draft of the State Revenue and Expenditure Budget.

The results of the discussion were then submitted to the Minister of Finance to be used as material for the preparation of the draft law on the next year's APBN. The Central Government then makes a Law Plan regarding the State Revenue and Expenditure Budget. Decision making is at the People's Representative Council session. The State Revenue and Expenditure Budget that has been ratified into law, implementation details are poured into a Presidential Regulation on the details of the Revenue and Expenditure Budget. The Minister of Finance allows each minister / agency leader to prepare budget execution documents based on budget allocations specified in the Presidential Regulation. For this reason, each state ministry / agency must be able to make financial reports on the budget that can be accounted for.

To obtain a central government accounting system in accordance with the law. Then there must be continuity between the regional financial accounting system which also follows the law. The administration of government in the regions also needs to be supported by a fast, accurate and accurate financial management system. The renewal of regulations on regional financial management was marked by the issuance of Government Regulation No. 58 of 2005 concerning Regional Financial Management and followed up with technical guidelines for the implementation of Government Regulation No. 58 of 2005 with the enactment of Minister of Domestic Affairs Regulation No. 13 of 2006 concerning Guidelines for Regional Financial Management. The accounting system developed by regional governments in the future must refer to the Minister of Home Affairs Regulation No. 13 of 2006, Government Regulation No. 58 of 2005 and this Government Regulation No. 24 of 2005.

With the enactment of a package of laws in the field of state finance, the regional government has an adequate and reliable legal basis for reforming regional financial management. So in accordance with Law No. 17 of 2003, the Government in the first phase has established Government Regulation No. 24 of 2005 concerning Government Accounting Standards. The Government Accounting Standards use the cash basis for the recognition of income, expenditure and financing and the accrual basis for the recognition of assets, liabilities and equity funds. In other words the basis used is the cash basis to accruals. The cash basis to accruals was applied in general in 2005.

In Indonesia, in developing public sector accounting, government accounting is contained in government accounting standards in the attachment to Government Regulation No. 71 of 2010 which then replaces Government Regulation No. 24 of 2005 in the form of Government Accounting Standards Number 01-12. The most striking look different is PSAP 12, because the Government Regulation No. 24 of 2005 does not discuss Operational Reports at all, while the Government Regulation No. 71 of 2010 is discussed.

The move from the cash basis to the accrual basis to the accrual basis because the accrual basis is one of the characteristics of modern financial management practices in the public sector. Simply put, the application of accrual-based accounting is intended to overcome the inadequacy of the cash base to provide more accurate data. The aim is to provide more transparent information about government costs and improve the quality of decision making in government using expanded information.

The accrual basis that is determined as part of the decision in the management of state finances must comply with statutory regulations. In this case, there needs to be conformity and consistency in the recognition of transactions that occur in the elements or transaction items for 
recognition of income and expenditure which is in the legislation. However, it is seen that the implementation of the accrual-based government accounting system is still not perfect. In this case, it is still necessary to repeat and reconcile the financial statements of the Public Sector Organization to the financial statements of the Regional Financial Management Agency and Regional Assets. In fact, when the accrual-based accounting system is implemented in accordance with Government Regulation No. 71 of 2010 and Minister of Home Affairs Regulation No. 64 of 2013 is expected to support the use of the budget as a control technique and can provide a more accurate picture, although in terms of recording it is indeed a bit complex. This requires human resources trained in accounting for the accrual-based accounting records. So if the system is applied accordingly, the control function can work to prevent other corruption.

This study aimed to examine the application of government accounting systems in the Regional Financial and Asset Management Agency of Madiun Regency. Considering that the Regional Financial and Asset Management Agency is a Regional Government Work Unit as well as the Regional Financial Administration Officer. The method used in this study is a qualitative method. Namely the method that focuses on direct observation of the object under study to understand thoughts about the surrounding environment. Meanwhile, the results of this study indicate that the existence of a government accounting system has an impact on the human resources that do the recording.

\section{Research Method}

Qualitative research is defined as a process that tries to gain a better understanding of the complexities involved in human interaction. With the purpose and formulation of the problem that has been formulated, this research belongs to descriptive qualitative research. This is intended to obtain in-depth information about the application of the government accounting system to the Regional Financial and Asset Management Agency, so that the data can be adjusted to the actual facts. The object of this research is the Financial Management Agency and the Regional Assets of Madiun District. This research was conducted to analyze the Regional Financial and Asset Management Agency of Madiun Regency which has implemented a system in accordance with government accounting standards, bearing in mind Government Regulation No. 71 of 2010 and Minister of Home Affairs Regulation No. 64 of 2010 have been issued on a fully accrual basis. Unit of analysis is a particular unit that is counted as a research subject. The unit of analysis in this study is the financial statements, policies, financial report preparation activities and financial report reporting at the Regional Financial and Asset Management Agency and all paragraphs (and examples) of financial statements in PP No. 71 of 2010 and Permendagri 64 of 2013.

Data source

Primary data is qualitative data obtained directly from the informant, which is in the form of answers from interviews with the Head of the Regional Financial and Asset Management Agency, the Head of Assets and Accounting for the Regional Financial and Asset Management Agency, and the Head of the Accounting and Financial Sub-Division of the Financial Management Agency and Madiun Regency Regional Assets, and in the form of field observations at the Madiun Regency Financial and Asset Management Agency. Secondary data is quantitative data that has been obtained from sources - existing sources. The data is in the form of journals, articles, literature studies, records and budgeting documents, preparation of financial reports for the Regional Financial Management and Assets Agency of Madiun Regency 
Determination of Informants

The selection of informants is done by key person. According to Bungin (2009: 77), key person can be used if the researcher has understood the initial information about the object of research and research respondents. With the key person, researchers can directly conduct interviews with informants who are the focus of the research object.

As a source of data and to obtain information in this study required informants who are directly interested in the existing government accounting system at the Regional Financial and Asset Management Agency, among others:

Drs. Rori Priambodo, M.Sc as Head of the Regional Financial and Asset Management Agency. Drs. Ec. Margono, M.Sc as the Head of Assets and Accounting for the Regional Financial and Asset Management Agency.

Ririn Asmarani, SE as Head of the Sub-Division of Accounting and Financial Statements

Data collection technique

Observation, as a data collection technique sourced from direct observation of the process of planning, preparing and reporting financial statements. Observations were made to obtain a real picture of an event or event to answer research questions (Guba and Lincoln, 1981: 191-193). In this study, researchers used a non-participatory observation method, which is collecting data through observation of the object of observation but not actively involved in the life of the informant and only became an independent observer. So that researchers will only come periodically to the object of research.

Interview, is the process of communication or interaction separately to collect information with questions and answers between researchers and informants or research subjects (Emzir, 2010: 50). The interview method chosen in this study is this is an unstructured interview. Unstructured interviews are conducted with questions and answers without any structured and systematic interview guidelines for use in question and answer. This way the interview will occur naturally. Documentation, namely data collection techniques by documenting documents that have a special relationship with the problem being discussed in this study. These documents are classified as official documents which are considered capable of providing information, both internal and external official documents. These documents are journals, financial reports, all data sourced in archives or documents relating to the government accounting system

Data analysis technique 


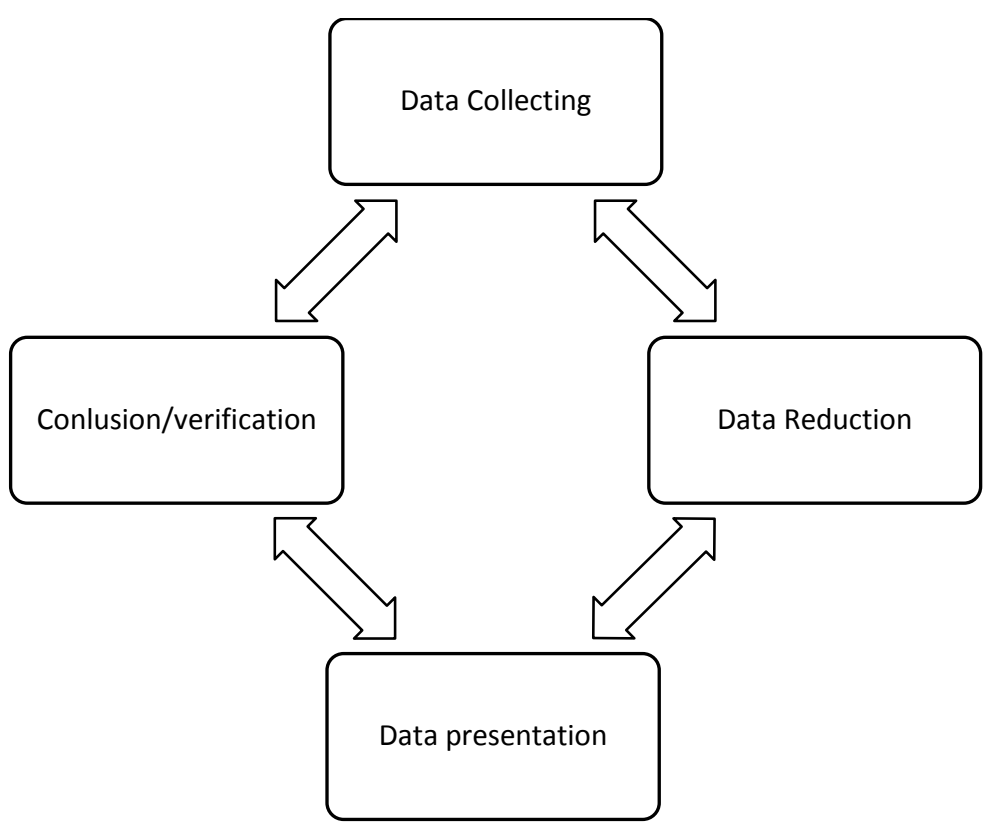

Source: Researcher, 2018

Data Validity Test

Examination of the data basically, in addition to being used to refute the alleged alleged qualitative research that is not scientific, is also an inseparable element of the body of qualitative research knowledge (Moleong, 2007: 320). The validity of the data is carried out to prove whether the data is valid and in accordance with the facts and circumstances. So that the data in qualitative research can be accounted for as scientific research needs to be tested data validity. The data validity test is carried out.

Credibility Test

Extension of observation can increase data confidence. With an extension of observation means the researcher returns to the field, conducts observations and interviews again with the data sources found or later. The extension of observation to test the credibility of research data is focused on testing the data that has been obtained. Data obtained after checking back to the field is correct or not, there are changes or still remain. After checking, then obtain data that can be accounted for. Then the data is credible and the extension of observation needs to be ended. Increasing diligence is done to control the work whether the data collected and presented is correct or not. To improve perseverance, researchers can be done by reading various references, books, previous research results and related documents by comparing the results of research that has been obtained. In this way researchers will be more careful in making reports that will be made more quality. Triangulation in the credibility test is the examination of data from various sources with various times. Sugiyono (2017: 273) argues that there are three types of triangulation, namely source triangulation, triangulation of data collection techniques and time triangulation.

\section{Result and Discussion}




\begin{tabular}{|l|l|l|l|}
\hline Budgetary & Cash & Revenue & Recording and \\
& Disbursement & Transaction & Responsibility \\
& Transactions & & \\
\hline
\end{tabular}




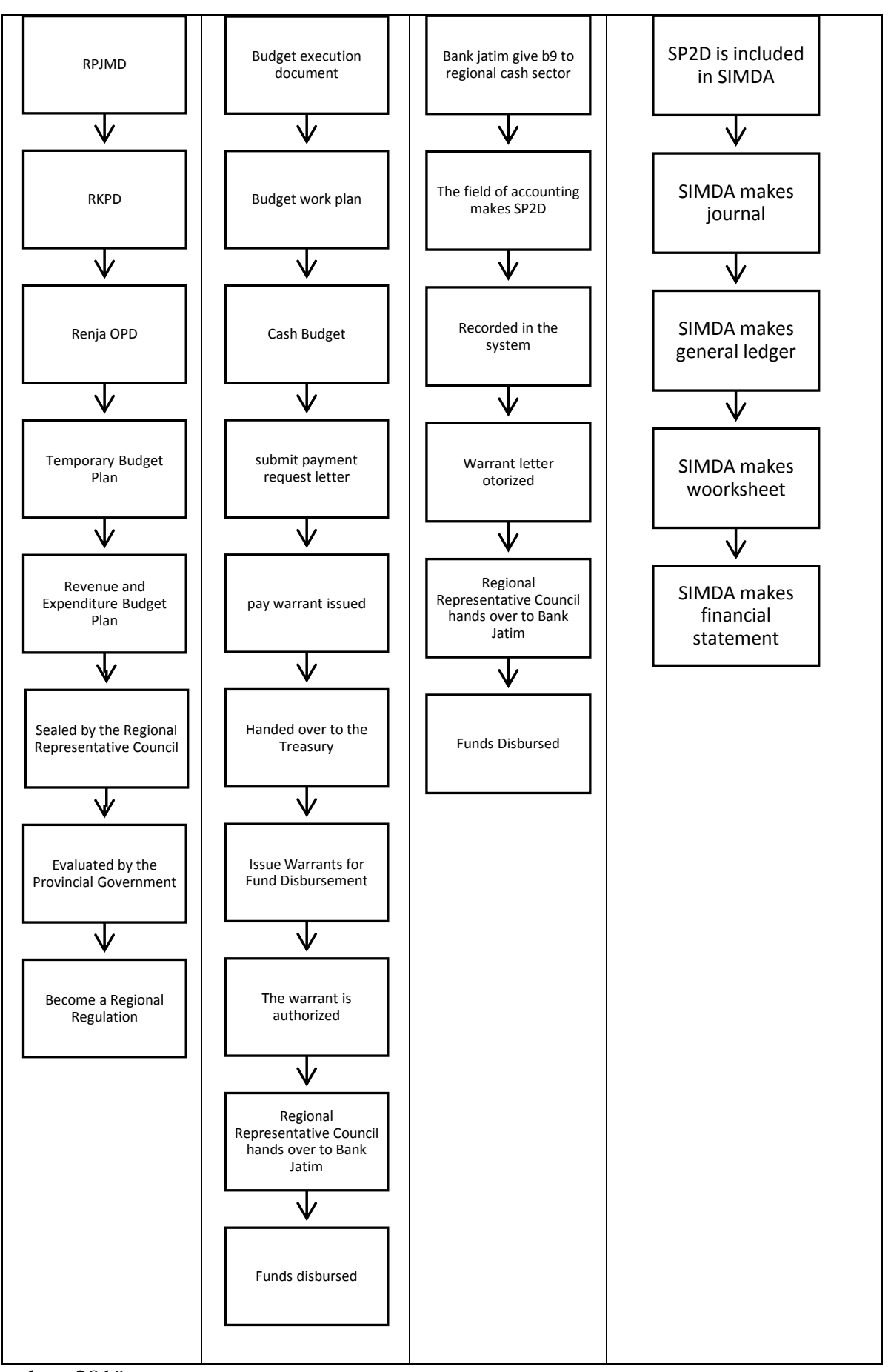

Source: Researcher, 2019 
The flow of the regional financial accounting system in the Regional Financial Management and Asset Management begins with the preparation of the Budget Plan. Budget plans are made through various stages and evaluations. Among them are RPJMD (Regional Medium Term Development Plan), RKPD (Regional Government Work Plan), Renja OPD (Regional Government Organization Work Plan) which still have to adjust to the vision and mission of the regent and vice regent, a Provisional Budget Plan created by the Agency Regional Development Planning is then inputted through SIMDA (Regional Management Information System).

After the SIMDA has been included by officials in the budget field, it has become a Regional Budget Revenue and Expenditure Plan (RAPBD) and then it is finalized with the House of Representatives. After being approved and corrected, the province must still be evaluated by the province and then become a regional regulation. When it becomes a regional regulation, the transaction can begin. Because all records are in SIMDA, transactions in DPA then make RKA included in the cash budget and a disbursement process occurs, where OPD makes SPP and SPM then submitted to the Treasury, completeness is checked, then the Accounting Sector issues SP2D after being authorized DPD submits to the Bank East Java to do the disbursement process In contrast to revenue, the recording is from B9, which makes Kasda from Bank Jatim. His opinion is entered here, his SP2D in the field of accounting who later posted from the post formed his own report along with additional journals outside of it.

Cash Receipt Accounting System

Regional income is divided into regional own revenue and transfer income.

Regional original income consists of regional taxes, regional levies, results of management of separated wealth, results of management of separated regional origin and etc. Legitimate regional original income

Transfer income consists of central government-balancing fund transfers, other central government transfers, other regional government transfers, financial assistance

Other regional income such as grant income from the government.

\begin{tabular}{|l|c|}
\hline Transaction & Document \\
\hline Income & $-\quad$ A letter of deposit \\
\hline Other legal income & $-\quad$ Proof of memorandum from Bank Jatim \\
\hline
\end{tabular}

Cash Expenditure Accounting System

Cash disbursement is generally referred to as expenditure. The Regional Financial and Asset Management Agency is known to have a spending and expense account which includes accounts for Operation Expenditures, Capital Expenditures, Unexpected Expenditures, Transfers. While account expenses include Employee Expenses - LO, Goods and Services Expenses, Subsidy Expenses, Grant Expenses, Social Assistance Expenses, Depreciation and Amortization Expenses, Allowance for Receivables, Other Expenses, Transfer Expenses for Regional Tax Results, Revenue Sharing Expenses Others, the burden of Financial Aid Transfers to the Village, Other Financial Aid Transfers. Operating expenses consist of Employee Expenditure, Goods and Services Expenditures, Subsidy Expenditures, Grant Expenditures and Social Assistance Expenditures consist of Land Capital Expenditures, Capital Expenditures for Equipment and Machines, Expenditures Building and Building Capital, Irrigation and Network Capital Expenditures, Other Fixed Asset Capital Expenditures and Other Asset Capital Expenditures 
Expenditure Expenditures Spending consisting of Financial Assistance Spending to Villages, Other Financial Assistance Spending (Assistance to Political Parties).

\begin{tabular}{|l|c|}
\hline Transaksi & Dokumen Sumber \\
\hline $\begin{array}{l}\text { Operating expenditure, capital } \\
\text { expenditures, unexpected } \\
\text { spending transfers }\end{array}$ & - Fund disbursement warrant \\
\hline
\end{tabular}

Liability Accounting System

On the Balance Sheet, it is known that the Regional Financial and Asset Management Agency has an Obligation. Namely Short-term Obligations in the form of Debt Expenses and Income Received in Advance, because in 2017 the Third Party Calculation Debt for death insurance contributions to BPKAD have been paid so that there is no Third Party Calculation Debt, Other short-term debt (Public Works Office of Bina Marga and Cipta Karya ) originated from the difference in physical value of the construction in progress as of December 31, 2016 on the construction of the Pavilion and the Construction of the Great Mosque of Madiun Regency due to the Head of the Public Works Department of Highways and Cipta Karya not reporting construction in progress according to the results of the stay as of December 31, 2016 according to physical realization which are actually. The work contract is a multi-year contract with a period of 600 calendar days from the SPMK dated November 2, 2015 to June 23, 2017 and a maintenance period of 180 calendar days which in 2017 has been paid.

\begin{tabular}{|l|c|}
\hline Transaction & Document \\
\hline $\begin{array}{l}\text { Third Party Calculation Debt, Prepaid } \\
\text { Income, Debt Expenses }\end{array}$ & $-\quad$ Bill of Charge \\
\hline
\end{tabular}

Financial statements

\begin{tabular}{|c|c|c|c|}
\hline $\begin{array}{l}\text { Used in PP No. } 71 \text { Tahun } \\
2013 \text { and Permendagri } \\
\text { No. } 64 \text { Tahun } 2010\end{array}$ & $\begin{array}{l}\text { Financial } \\
\text { Statements of the } \\
\text { Regional Financial } \\
\text { and Asset } \\
\text { Management } \\
\text { Agency of Madiun } \\
\text { Regency }\end{array}$ & $\begin{array}{l}\text { Suitable or } \\
\text { Not } \\
\text { Suitable }\end{array}$ & Information \\
\hline $\begin{array}{l}\text { Based on PP No. } 71 \text { of } \\
2013 \text { and Permendagri } \\
\text { No. } 64 \text { of 2010, the } \\
\text { components of the } \\
\text { financial statements used } \\
\text { are: } \\
\text { - Budget Realization } \\
\text { Report } \\
\text { - Report changes in } \\
\text { budget balances } \\
\text { more } \\
\text { - Balance Sheet }\end{array}$ & $\begin{array}{l}\text { The financial } \\
\text { statements consist of: } \\
\text { - Budget } \\
\text { Realization } \\
\text { Report } \\
\text { - Report Changes in } \\
\text { More Budget } \\
\text { Balance } \\
\text { - Balance Sheet } \\
\text { - Operational } \\
\text { report }\end{array}$ & Suitable & $\begin{array}{l}\text { The Regional } \\
\text { Financial } \\
\text { Management } \\
\text { and Asset } \\
\text { Management } \\
\text { Agency of } \\
\text { Madiun } \\
\text { Regency has } \\
\text { been given a } \\
\text { regional } \\
\text { management }\end{array}$ \\
\hline
\end{tabular}




\begin{tabular}{|c|c|c|}
\hline $\begin{array}{l}\text { - } \text { Operational } \\
\text { - } \text { report } \\
\text { Cash flow } \\
\text { statement } \\
\text { - } \text { Equity change } \\
\text { report } \\
\text { - Notes to financial } \\
\text { statements } \\
\text { - }\end{array}$ & $\begin{array}{ll}\text { - } & \text { Cash flow } \\
\text { statement } \\
\text { - } & \text { Statement of } \\
\text { changes in } \\
\text { equity } \\
\text { - Notes to financial } \\
\text { - } \\
\text { statements }\end{array}$ & $\begin{array}{l}\text { information } \\
\text { system } \\
\text { (SIMDA) that } \\
\text { makes financial } \\
\text { reports in } \\
\text { accordance } \\
\text { with PP No } 71 \\
\text { of } 2013 \text { and } \\
\text { PermendagriNo } \\
64 \text { of } 2010\end{array}$ \\
\hline
\end{tabular}

In a study conducted at the Regional Financial and Asset Management Agency in Madiun District, a mature system was produced which was assisted by the Regional Management Information System (SIMDA) which adjusted government regulations and accounting standards. Such as making the budget entered the system since the Provisional Budget Plan, then the approved Revenue and Expenditure Budget Plan, issuing disbursement and payment warrants, making transactions-related journals, working papers to financial reports - financial statements Must be made for accountability, starting from the budget realization report, statement of changes in excess budget balance, balance sheet, operational report, cash flow statement, equity change report and notes to the report

Analysis of the Application of Government Accounting Systems in Badan Pengelola Keuangan dan Aset Daerah Kabupaten Madiun

\begin{tabular}{|c|c|c|c|}
\hline $\begin{array}{l}\text { Government } \\
\text { Accounting } \\
\text { System }\end{array}$ & 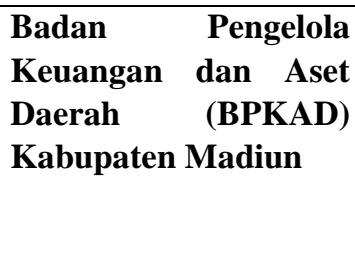 & $\begin{array}{l}\text { PP. No } 71 \\
\text { Tahun } 2010 \\
\text { and } \\
\text { Permendagri } \\
\text { No 64 } \\
2013\end{array}$ & Information \\
\hline $\begin{array}{l}\text { Accounting for } \\
\text { Cash Receipts }\end{array}$ & $\begin{array}{l}\text { Accounting for cash } \\
\text { receipts at BPKAD in } \\
\text { Madiun Regency } \\
\text { consists of Revenue - } \\
\text { LO and LRA Revenues } \\
\text { whose revenues are } \\
\text { derived from Regional } \\
\text { Original Revenues, } \\
\text { Transfer Revenues and } \\
\text { Other Legitimate } \\
\text { Revenues. }\end{array}$ & $\begin{array}{lr}\text { Accounting } & \text { for } \\
\text { Cash Receipts } \\
\text { consists } r \\
\text { Revenues } & \text { - LO } \\
\text { and } & \text { LRA } \\
\text { derived from } \\
\text { Regional } \\
\text { Original } \\
\text { Revenues, } \\
\text { Transfer } \\
\text { Revenues and } \\
\text { Other } \\
\text { Legitimate } \\
\text { Revenues. }\end{array}$ & Suitable \\
\hline
\end{tabular}




\begin{tabular}{|c|c|c|c|}
\hline $\begin{array}{l}\text { Accounting for } \\
\text { Cash } \\
\text { Expenditures }\end{array}$ & $\begin{array}{l}\text { Accounting for BPKAD } \\
\text { cash expenditure in } \\
\text { Madiun Regency } \\
\text { consists of Expenses } \\
\text { and Expenditures.The } \\
\text { intended expenditure is } \\
\text { operating expenditure, } \\
\text { capital } \\
\text { expenditure, unexpected } \\
\text { expenditure, transfer } \\
\text { expenditurer While } \\
\text { account expenses, there } \\
\text { are Employee Expenses } \\
\text { - LO, Goods and } \\
\text { Services Expenses, } \\
\text { Subsidies Expenses, } \\
\text { Grant Expenses, Social } \\
\text { Assistance Expenses, } \\
\text { Depreciation and } \\
\text { Amortization Expenses, } \\
\text { Allowancer for } \\
\text { Receivables, Other } \\
\text { Expenses, Transfers } \\
\text { Expenses for Local } \\
\text { Taxes, Revenue Sharing } \\
\text { Expenses Other income, } \\
\text { expense of transfer of } \\
\text { financial assistance to } \\
\text { the village, other } \\
\text { expenses of transfer of } \\
\text { financial assistance }\end{array}$ & $\begin{array}{l}\text { Accounting } \\
\text { Cash } \\
\text { expenditure } \\
\text { consists } \\
\text { operating } \\
\text { expenses, } \\
\text { capital } \\
\text { expenditure, } \\
\text { other expenses / } \\
\text { unexpected, } \\
\text { outgoing } \\
\text { transfers. As for } \\
\text { expenses, using } \\
\text { the account of } \\
\text { Interest } \\
\text { Expense, } \\
\text { Subsidy } \\
\text { Expense, Grant } \\
\text { Expense, Social } \\
\text { Assistance } \\
\text { Expense, } \\
\text { Transfer } \\
\text { Expense, }\end{array}$ & Suitable \\
\hline $\begin{array}{l}\text { Liability } \\
\text { Accounting } \\
\text { System }\end{array}$ & $\begin{array}{l}\text { BPKAD Kabupaten } \\
\text { Madiun has Short-term } \\
\text { Debt but does not have } \\
\text { Long-term Debt in the } \\
\text { fiscal year }\end{array}$ & $\begin{array}{l}\text { Accounting for } \\
\text { Obligations } \\
\text { consists of Long } \\
\text { Term } \\
\text { Obligations and } \\
\text { Short Term } \\
\text { Obligations }\end{array}$ & Suitable \\
\hline
\end{tabular}

Based on the Accounting System for Cash Receipts, the Regional Financial Management Agency and the Regional Assets of Madiun Regency have made LO-Income and LRA Income, whose revenues are derived from Regional Original Income, Transfer Income and other Revenues such as grant funds. The use of SIMDA also makes it easier so it does not allow formatting errors. This SIMDA has been used since 2013. 
Accounting for Cash Expenditures is carried out through SP2D issuance and then liquid funds. The recording of SP2D in the system directly helps to keep a journal to the financial statements needed. The Madiun Regency Regional Treasury and Cash Assets cash expenditure accounting system consists of expenditures where there is money supply and direct expenditure.

Accounting for the Obligations of the Regional Financial and Asset Management Agency of Madiun Regency is also carried out using SIMDA so that it automatically follows Government Regulation No. 71 of 2010 and Minister of Home Affairs Regulation No. 64 of 2013. With the entry of billing statements on SIMDA, the journals to the required financial statements are already listed in SIMDA.

What still needs to be done by the Regional Financial and Asset Management Agency is to reconcile at the end of the year before the Notes to the Financial Statements are made so that there are no calculation errors. Considering that each Local Government Organization does not always have accounting personnel to make entries for journal posts. So often there are still errors in the recording before the Financial Statement Notes that make the Madiun District Financial and Asset Management Agency work twice before then making the Consolidated Financial Statements.

\section{References}

\section{Text Book :}

[1] Arif, Bachtiar dkk. 2002. Akuntansi Pemerintahan. Jakarta: Salemba Empat

[2] Baridwan, Zaki. 2009. Sistem Akuntansi Penyusunan Prosedur dan Metode. Yogyakarta: YKPN

[3] Bastian, Indra, 2006. Akuntansi Sektor Publik: Suatu Pengantar. Jakarta: Erlangga

[4] Bastian, Indra. 2011. Sistem Akutansi Sektor Publik. Jakarta: Salemba Empat

[5] Belakoui, Ahmed Riahi. 2006. Accounting Theory: Teori Akuntansi. Edisi Kelima. Jakarta: Salemba Empat

[6] Bungin, Burhan. 2007. Penelitian Kualitatif : Komunikasi, Ekonomi, Kebijakan Publik dan Ilmu Sosial Lainnya. Jakarta : Kencana Prenadamedia Group

[7] Peraturan Daerah Tentang Pertanggungjawaban Pelaksanaan APBD Kabupaten Madiun Tahun Anggaran 2017

[8] Emzir. 2010. Metodologi Penelitian Pendidikan: Kuantitatif dan Kualitatif. Jakarta: Rajawali Pers

[9] Gade, Muhammad. 2000. Akuntansi Pemerintahan. Jakarta: Lembaga Penerbit Fakultas Ekonomi Universitas Indonesia

[10] Guba, Lincoln. 1981. Effective Evaluation. San Fransisco: Jossey Bass Publisher

[11] Halim, Abdul. 2004. Akuntansi Keuangan Daerah. Jakarta: Salemba Empat

[12] Harahap, Sofyan Syafri. 2015. Analisis Kritis atas Laporan Keuangan. Edisi 1-10. Jakarta: Rajawali Pers

[13] Hery. 2017. Teori Akuntansi: Pendekatan Konsep dan Analisis. Jakarta: Grasindo

[14] Jonathan, Sarwono. 2006. Metode Penelitian Kuantitatif dan Kualitatif. Yogyakarta: Graha Ilmu

[15] McLeod,Jr., Raymond; Schell, George P. 2011. Sistem Informasi Managemen (Terjemahan). Jakarta: PT Gramedia

[16] Moleong, Lexy J. 2001. Metodologi Penelitian Kualitatif. Bandung: Remaja Rosdakarya

[17] Mulyadi. 2014. Sistem Akuntansi. Jakarta: Salemba Empat 
[18] Muri, Yusuf. 2014. Metode Penelitian Kuantitatif, Kualitatif \& Penelitian Gabungan. Jakarta: Prenadamedia group

[19] Peraturan Pemerintah Republik Indonesia No 71 Tahun 2010 Tentang Standar Akuntansi Pemerintahan

[20] Peraturan Menteri Dalam Negeri Republik Indonesia Nomor 64 Tahun 2013 Tentang Penerapan Standar Akuntansi Pemerintahan Berbasis Akrual Pada Pemerintah Daerah

[21] Reeve, James M.; Warren, Carl S. 2009. Pengantar Akuntansi Adaptasi Indonesia Buku 1. Jakarta: Salemba Empat

[22] Romney, Marshall B.; Steinbart, Paul John. 2015. Sistem Informasi Akuntansi. Edisi 13. Jakarta: Salemba Empat

[23] Rusmana, Oman, dkk. 2017. Akuntansi Pemerintahan Daerah. Jakarta: Salemba Empat

[24] Soemarso, S.R. 2004. Akuntansi Suatu Pengantar. Edisi Lima. Jakarta: Salemba Empat

[25] Sugiyono. 2005. Memahami Penelitian Kualitatif. Bandung. Alfabeta

[26] Sugiyono. 2007. Metode Penelitian Kuantitatif, Kualitatif dan $R \&$ \&. Bandung : Alfabeta.

[27] Sugiyono. 2011. Metode Penelitian Kuantitatif Kualitatif dan R\&D. Bandung: Alfabeta

[28] Sugiyono. 2013. Metodelogi Penelitian Kuantitatif, Kualitatif dan R\&D. Bandung: Alfabeta

[29] Yabbar, Rahmah; Hamzah, Ardi. 2015. Akuntansi Pemerintahan Berbasis Akrual. Surabaya: Pustaka

[30] H. S. R. Evaluasi, P. Akuntansi, E. Penerapan, A. Berbasis, A. Pada, and D. Pekerjaan, "EVALUATION OF THE APPLICATION OF ACCRUAL BASED ACCOUNTING IN THE PUBLIC,” vol. 7, no. 4, pp. 5009-5018.

[31] O. Yani, F. Singkali, F. Ekonomi, and U. K. Petra, "Dinas Pendapatan Dan Pengelolaan Keuangan Aset Daerah ( Dppkad ) Kabupaten Toraja Utara Abstract :," vol. 4, no. 2, pp. 1-15, 2014.

[32] A. Martinench, "No Title,," Pontif. Univ. Catol. del Peru, vol. 8, no. 33, p. 44, 2014. 